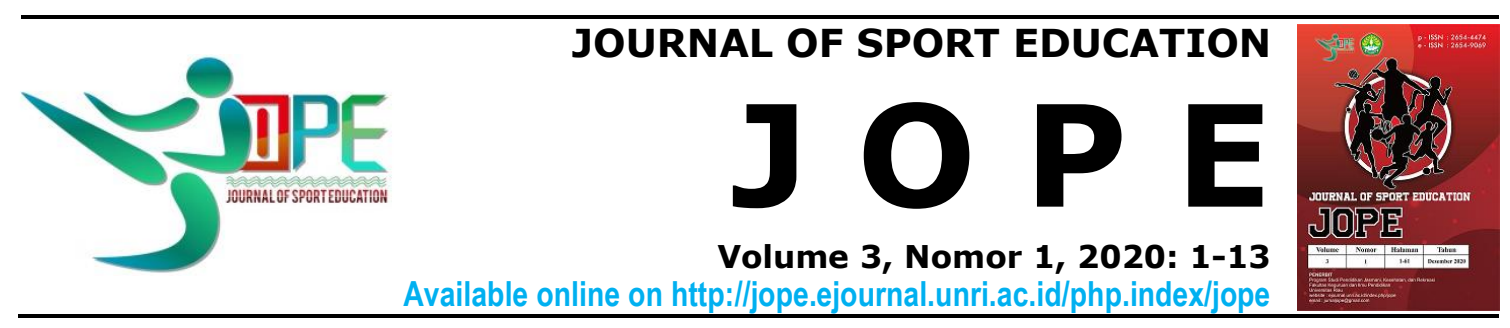

\title{
Shooting free throw: Apakah dipengaruhi imagery dan keyakinan diri?
}

\author{
Fitri Agung Nanda ${ }^{1}$, Novriansyah ${ }^{2}$, Muhammad Imam Rahmatullah ${ }^{3}$, Candra Widiastuti ${ }^{4}$, Sigit \\ Dwi Andrianto ${ }^{5}$ \\ 1,2,3,5 Universitas Negeri Yogyakarta, ${ }^{4}$ Universitas Sebelas Maret \\ fitriagungnanda16@gmail.com ${ }^{1}$, novripenjas09@gmail.com² ${ }^{2}$, \\ muhammadimamrahmatullah@gmail.com ${ }^{3}$, candrawidiastuti3@gmail.com ${ }^{4}$, \\ sigitdwiandrian11@gmail.com ${ }^{5}$
}

Received: 22 Juli 2020; Revised: 5 Agustus 2020; Accepted: 16 Agustus 2020

doi) http://dx.doi.org/10.31258/jope.3.1.1-13

\begin{abstract}
Abstrak
Tujuan penelitian ini adalah untuk mengetahui adakah interaksi yang terjadi antara latihan imagery dan keyakinan diri yang mempengaruhi hasil dari shooting free throw ekstrakurikuler bola basket. Penelitian menggunaakan metode eksperimen faktorial $2 \times 2$. Sampel pada penelitian ini yaitu peserta ekstrakurikuler bola basket sebanyak 40 orang di Kabupaten Bantul. Instrumen mengukur tingkat keyakinan diri menggunakan angket keyakinan diri dan hasil shooting free throw dengaan menggunakan shooting free throw test yang adopsi dari Arianto B. Analisis data menggunakan analisis of variance (ANAVA) dua jalur pada taraf signifikan $\alpha=$ 0,05 . Hasil penelitian dinyatakan bahwa tdak terdapat interaksi antara latihan imagery dan keyakinan diri tarhadap hasil shooting free throw ekstrakurikuler bola basket, terbukti dengan nilai sig $=0,835>0,5$
\end{abstract}

Kata Kunci: imageri, keyakinan diri, shooting free throw

\section{Free throw shooting: Is affected by imagery and self-efficacy?}

\begin{abstract}
The purpose of this research is to find out whether there are an interaction between imagery training and self-confidence that affects the results of basketball extracurricular free throw shooting. The study used a $2 \times 2$ factorial experimental method. The population in this study were basketball extracurricular with 40 participants in Bantul Regency. The instrument measures the level of confidence using a self-confidence questionnaire and the results of the free throw shooting using the free throw throw test adopted from Arianto B. Analysis of the data uses an analysis of variance (ANAVA) of two paths at a significant level $\alpha=0.05$. The results of the study stated that there was no interaction between imagery training and self-confidence towards the basketball extracurricular free throw shooting results, as evidenced by the sig $=0.835>0.5$.
\end{abstract}

Keywords: imagery, self-efficacy, shooting free throw

How To Cite: Nanda, F. A., Novriansyah., Rahmatullah, M. I., Widiastuti, C., Andrianto, S. D. (2020). Shooting free throw: apakah dipengaruhi imagery dan keyakinan diri?. Journal of Sport Education (JOPE), $3(1), 1-13$

\section{INTRODUCTION}

Extracurricular activities are one of the media in the process of fostering sports achievement in the school. In terminology as written in the attachment to the Decree of the Minister of Education and Culture number 
Journal of Sport Education (JOPE), 3 (1) 2020 - 2

Fitri Agung Nanda ${ }^{1}$, Novriansyah ${ }^{2}$, Muhammad Imam Rahmatullah ${ }^{3}$, Candra Widiastuti ${ }^{4}$, Sigit Dwi Andrianto ${ }^{5}$

060 / U1993 and number 080 / U / 1993 that:

Extracurricular activities carry out after the end of class hours which are listed and scheduled in a school in accordance with conditions of the school. Extracurricular activities are enrichment and improvement activities related to the curricular program. Suryosubroto, (2007: 35) explains that extracurricular activity is an additional activity and outside the scheduled learning structure with the aim to enrich and broaden students' knowledge and skills. Wibowo \& Andriyani, (2015: 2) states that extracurricular activities are non-formal activities conducted outside school hours with the aim to develop students' talents, attitudes, abilities, and personalities. Of the several sports found in extracurricular activities at school, basketball is one of the favorite sports for students. Also, basketball is one of the most popular sports in the world (Ziv \& Lidor, 2010: 332). Basketball is a sport played by five people in each team and is played in four quarters; the winner is the team which reaches the highest points over four quarters by putting the ball into the opponent's ring (FIBA, 2012: 5). Castagna, Impellizzeri, Rampinini, D'Ottavio, \& Manzi, ( 2008: 202), basketball is a sport that is intermittent with high intensity because it is a mental and physical game due to basketball is a fast sport and very energydraining. If the player does not have good energy, then the player will experience a decrease in focus.

Basketball has a variety of basic techniques such as passing, shooting, and dribbling. The most commonly taught technique in basketball is shooting. Shooting is a basic technique in basketball which has an important role although it is one of the easiest techniques to teach, (Wissel 2012: 72). Furthermore, he explained that shooting in basketball consists of various kinds, such as shooting two points, shooting three points, shooting free throw (free shots). Shooting free throw is a free shot obtained when the opposing player violates a player of the attacker team. Shooting free throw goes two or three times in one offense committed, and each point generated in one shot free throw is one point. In shooting free throw, a player needs to shoot the ball from the line of freethrow without jumping, besides the player must also have good abilities such as eye and hand coordination, good arm muscle strength and body position, while from a psychological view, a player must have concentration, self-efficacy, and calmness in shooting. Wissel (2012: 83) states that success in shooting free throw requires selfefficacy, routine, relaxation, rhythm, and concentration. Based on the previous opinions, it concluded that not only technique, but the psychological factor is also an important role in shooting a free throw. Supported by Irianto, D. P. (2018: 101) states that besides physical factors, techniques and tactics, in sports are also determined by mental readiness or psychological maturity, because in many cases, it often happens that a player or a team that has good physical techniques and tactics loses in competition. 
Journal of Sport Education (JOPE), 3 (1) 2020 - 3

Fitri Agung Nanda ${ }^{1}$, Novriansyah ${ }^{2}$, Muhammad Imam Rahmatullah ${ }^{3}$, Candra Widiastuti ${ }^{4}$, Sigit Dwi Andrianto ${ }^{5}$

At the time of going to shooting a free throw, the player needs good imagery. In line with this statement, Yu et al., (2015: 7) states that imagery is an important training of mental exercise for athletes. Supported by Post, Wrisberg, \& Mullins, (2010) explains that someone who has good imagery succeeded in performing free throw compared to those who have weak imagery. Weinberg \& Gould, (2011: 284) states that imagery is a stimulation, or is similar to real sensory experiences (for example, see, feel, or hear), but, all these experiences occur in the mind. Imagery exercises in this study are internal and external imagery exercises. Besides the imagery, performing shooting free throw also requires self-efficacy, because if the player lacks confidence will cause the player doubting, and failure as the worst impact. In line with the previous opinion, Wicaksono, A (2012:) explains that self-efficacy in performing shooting free throw is an important factor that must be possessed because is related to the accuracy of shooting. Wissel, (2012: 84) states that selfefficacy is an important part of shooting because it will increase the player's confidence in shooting. In short, self-efficacy might state as having a role in shooting a free throw.

Based on the literature study, imagery and self-efficacy are very important components possessed by basketball players to maximize them in performing free throws. However, the authors note that there is still a lack of research that discusses imagery and selfefficacy among basketball players when performing free throws which are discussed or researched simultaneously. Therefore, the authors assess the need for a renewal of the research on the influence of imagery and self-efficacy of basketball players in performing shooting free throws. The subjects in this study were students who took the basketball extracurricular activity in Bantul district, consisted of 3 schools, namely SMPN 3 Jetis, SMPN 1 Bantul and SMPN 3 Bantul with a total of 40 students. A reaserch used quesionnaire instrument to measure self-efficacy while results of shooting free throw using the shooting free throw test adopted from Arianto B.

\section{METHOD}

The particular research used an experimental method. This reaserch study involved two groups that received different treatments in the forman exercise method combined with aerobic endurance. The experimental research method interprets as a research method used to examine the effect of certain treatments on others under controlled conditions, the experimental research method is quantitative research (Sugiyono, 2018:109). The influence observed in this particular research was self-efficacy and imagery. Subjects were male students who took basketball extracurricular activities at SMPN 1 Bantul, SMPN 3 Bantul, and SMPN 3 Jetis, with a total of 40 people. Data collection in this study used a questionnaire self abolityintending to measure the efficacy of students who took basketball extracurricular activities and provide free 
Journal of Sport Education (JOPE), 3 (1) 2020 - 4

Fitri Agung Nanda ${ }^{1}$, Novriansyah ${ }^{2}$, Muhammad Imam Rahmatullah ${ }^{3}$, Candra Widiastuti ${ }^{4}$, Sigit Dwi Andrianto ${ }^{5}$

throw tests conducted at the pre-test. And, after the pre-test, students continued to the treatment of internal and external imagery. In the end, the students provided a final test (post-test). The data analysis technique on the hypothesis test was the analysis of variance (ANOVA) two paths. Hypothesis test used a significance level $\alpha=0.05$. Furthermore, the Tukey test used to compare the average pair of treatments (Sudjana, 2002: 36). Validity and reliability of the instrument of self-efficacy, considering the questionnaire in this study was newly prepared for this study, then the instrument of the self-efficacy questionnaire must pass the content validity, and then validated by the validator (expert judgment).

Table 1. Self - efficacy

\begin{tabular}{|c|c|c|c|c|}
\hline Variable & Items & $\mathrm{R}_{\text {count }}$ & $\mathrm{r}_{\text {table }}$ & Description \\
\hline \multirow{16}{*}{ Self - efficacy } & 1 & 0,667 & 0,3388 & Oke \\
\hline & 2 & 0,723 & 0,3388 & Oke \\
\hline & 3 & 0,471 & 0,3388 & Oke \\
\hline & 4 & 0,386 & 0,3388 & Oke \\
\hline & 5 & 0,061 & 0,3388 & Oke \\
\hline & 6 & 0,674 & 0,3388 & Oke \\
\hline & 7 & 0,589 & 0,3388 & Oke \\
\hline & 8 & 0,489 & 0,3388 & Oke \\
\hline & 9 & 0,672 & 0,3388 & Oke \\
\hline & 10 & 0,712 & 0,3388 & Oke \\
\hline & 11 & 0,506 & 0,3388 & Oke \\
\hline & 12 & 0,380 & 0,3388 & Oke \\
\hline & 13 & 0,400 & 0,3388 & Oke \\
\hline & 14 & 0,374 & 0,3388 & Oke \\
\hline & 15 & 0,244 & 0,3388 & Oke \\
\hline & 16 & 0,426 & 0,3388 & Oke \\
\hline
\end{tabular}

The results of the validity of 16 items with 34 people as respondents, obtained 2 invalid items namely numbers 5 and 15 . This item was invalid when the $r_{\text {count }}<r_{\text {table }}$ at a significant level of $5 \%$, then the item is invalid. From the data of respondents of 34 people obtained $\mathrm{r}_{\text {table }}=0,3388$.

Table 2. Result of Reliability Test of the self-efficacy questionnaire

\begin{tabular}{c|c}
\hline \multicolumn{2}{c}{ Reliability Statistics } \\
\hline Cronbach's Alpha & Nof Items \\
\hline 0,776 & 16 \\
\hline
\end{tabular}

The results after reliability test of the motivation questionnaire instrument using the SPSS application obtained a reliability value of 0.776 .

\section{RESULT AND DISCUSSION}

\section{Result}

The analysis result of the main influence between the independent variable of imagery method and the attribute variable of selfefficacy toward the dependent variable of shooting free throw on basketball extracurricular participants. The results of 
Journal of Sport Education (JOPE), 3 (1) 2020 - 5

Fitri Agung Nanda ${ }^{1}$, Novriansyah ${ }^{2}$, Muhammad Imam Rahmatullah ${ }^{3}$, Candra Widiastuti ${ }^{4}$, Sigit Dwi Andrianto ${ }^{5}$

data analysis in the hypothesis test are:

The intraction between imagery training and self-efficacy toward ability of shooting free throw of basketball extracuricular

The results of the first analysis aimed to find out the significant differences between the interactions of imagery training and selfefficacy toward shooting free throw abilities of basketball extracurricular. The results of the statistical calculation using SPSS 21 were:

Table 3. Summary of ANOVA Interaction Results from Both Imagery Training and Self-Efficacy in Shooting Free Throw:

\begin{tabular}{c|c|c|c|c|c}
\hline Source & Type III Sum of Squares & $d f$ & Mean Square & $F$ & Sig. \\
\hline Self Efficacy* Imagery & 0,025 & 1 & 0,025 & 0,044 & .835 \\
\hline
\end{tabular}

In concluding, if: (1) If the sig value is greater or equal to 0.05 ( $\mathrm{sig} \geq 0,05$ ), then $\mathrm{H}_{0}$ is accepted and $\mathrm{H}_{\mathrm{a}}$ is rejected. This means, have no significant differences between the interactions of the imagery training and selfefficacy toward the results of shooting free throw of basketball extracurricular. (2) If the sig value is smaller or equal to the value of 0.05 ( $\operatorname{sig} \leq 0,05$ ), then $\mathrm{H}_{0}$ is rejected and $\mathrm{H}_{\mathrm{a}}$ is accepted. This means, there is a significant difference between the interactions of the imagery training and self-efficacy toward the results of shooting free throw of basketball extracurricular. Based on the ANOVA test analysis results, the value of $\operatorname{sig}=0.835 \geq$
0.05 , then $\mathrm{H}_{0}$ is accepted and $\mathrm{H}_{\mathrm{a}}$ is rejected. In short, there is no significant difference between the interaction of the imagery training and self-efficacy toward the results of shooting free throw of basketball extracurricular. Thus, the third hypothesis states that there is no significant difference between the interactions of the imagery training and self-efficacy toward the results of shooting free throw of basketball extracurricular. Figure 1 is a graphic that shows the lack of interaction between the imagery training and self-efficacy toward the results of shooting free throw of basketball

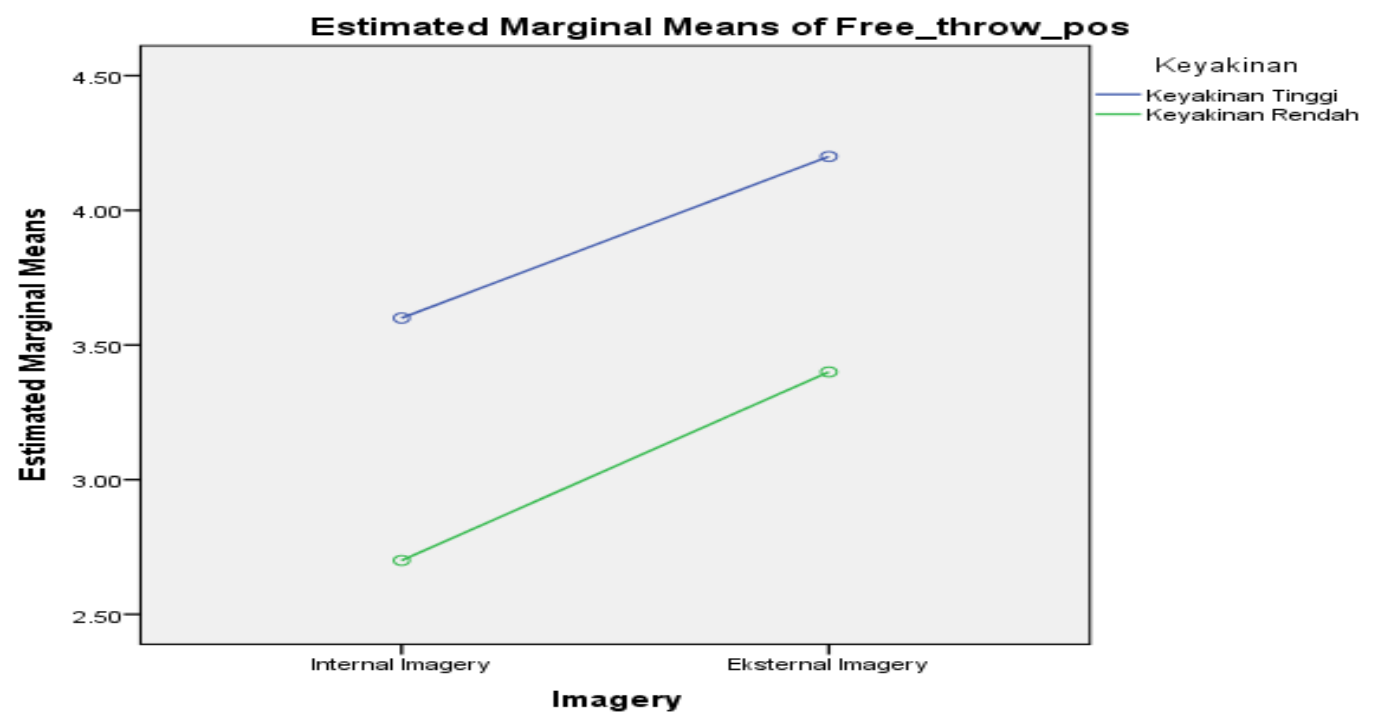


Journal of Sport Education (JOPE), 3 (1) 2020 - 6

Fitri Agung Nanda ${ }^{1}$, Novriansyah ${ }^{2}$, Muhammad Imam Rahmatullah ${ }^{3}$, Candra Widiastuti ${ }^{4}$, Sigit Dwi Andrianto ${ }^{5}$

Figure.1 Image of interaction between imagery training and self-efficacy

After the third hypothesis test which states that there is no significant difference between the interactions of the imagery training and self-efficacy toward the results of shooting free throw of basketball extracurricular, it needs to conduct advanced tests using the Post Hoc test. The results of advanced tests using the Post Hoc test were:

Table 4. Analysis Results of the Advanced Test Using the Post Hoc Test.

\begin{tabular}{|c|c|c|c|c|c|c|}
\hline \multirow{2}{*}{ (I) Group } & \multirow{2}{*}{ (J) Group } & \multirow{2}{*}{ Mean Difference (I-J) } & \multirow{2}{*}{ Std. Error } & \multirow{2}{*}{ Sig. } & \multicolumn{2}{|c|}{ 95\% Confidence Interval } \\
\hline & & & & & Lower Bound & Upper Bound \\
\hline A1B1 & $\begin{array}{l}\text { A2B1 } \\
\text { A1B2 } \\
\text { A2B2 } \\
\end{array}$ & $\begin{array}{l}-.60000 \\
.90000 \\
.20000 \\
\end{array}$ & $\begin{array}{l}.33747 \\
.33747 \\
.33747 \\
\end{array}$ & $\begin{array}{l}.300 \\
.053 \\
.934 \\
\end{array}$ & $\begin{array}{l}-1.5089 \\
-.0089 \\
-.7089 \\
\end{array}$ & \begin{tabular}{|l|}
.3089 \\
1.8089 \\
1.1089 \\
\end{tabular} \\
\hline $\mathrm{A} 2 \mathrm{~B} 1$ & $\begin{array}{l}\text { A1B1 } \\
\text { A1B2 } \\
\text { A2B2 } \\
\end{array}$ & $\begin{array}{l}.60000 \\
1.50000^{*} \\
.80000\end{array}$ & $\begin{array}{l}.33747 \\
.33747 \\
.33747 \\
\end{array}$ & $\begin{array}{l}.300 \\
.000 \\
.101 \\
\end{array}$ & $\begin{array}{l}-.3089 \\
.5911 \\
-.1089 \\
\end{array}$ & \begin{tabular}{|l}
1.5089 \\
2.4089 \\
1.7089 \\
\end{tabular} \\
\hline A1B2 & $\begin{array}{l}\text { A1B1 } \\
\text { A2B1 } \\
\text { A2B2 } \\
\end{array}$ & $\begin{array}{l}-.90000 \\
-1.50000^{*} \\
-.70000\end{array}$ & $\begin{array}{l}.33747 \\
.33747 \\
.33747 \\
\end{array}$ & $\begin{array}{l}.053 \\
.000 \\
.181 \\
\end{array}$ & $\begin{array}{l}-1.8089 \\
-2.4089 \\
-1.6089 \\
\end{array}$ & $\begin{array}{l}.0089 \\
-.5911 \\
.2089\end{array}$ \\
\hline $\mathrm{A} 2 \mathrm{~B} 2$ & $\begin{array}{l}\text { A1B1 } \\
\text { A2B1 } \\
\text { A1B2 }\end{array}$ & $\begin{array}{l}-.20000 \\
-.80000 \\
.70000\end{array}$ & $\begin{array}{l}.33747 \\
.33747 \\
.33747 \\
\end{array}$ & $\begin{array}{l}.934 \\
.101 \\
.181 \\
\end{array}$ & $\begin{array}{l}-1.1089 \\
-1.7089 \\
-.2089\end{array}$ & \begin{tabular}{|l}
.7089 \\
.1089 \\
1.6089 \\
\end{tabular} \\
\hline
\end{tabular}

*.The mean difference is significant at the 0.005 level

Based on table 2, the results of the post hoc test had the asterisk (*) which showed the pairs of groups that have interactions or groups with significant differences: (1) A2B1-A1B2, and (2) A1B2-A2B1. Thus, concluded that:

a. A2B1-A1B2: If a group of students in basketball extracurricular who are parctice with the external imagery method with high self-efficacy is succes in a group of students in basketball extracurricular who are parctice with the internal imagery method with low selfefficacy, then there are significant differences. The group of students who are parctice with the external imagery method with high self-efficacy was better than students who are parctice with the internal imagery method with low selfefficacy, with a significant value of 0.000 $<0.05$.

b. A1B2-A1B1: If a group of students in basketball extracurricular who accepted using the internal imagery method with low self-efficacy is succes a group of students in basketball extracurricular who are practice with the external imagery method with high self-efficacy, then there are significant differences. The group of students who are practice with the external imagery method with high selfefficacy was better than students who are 
Fitri Agung Nanda ${ }^{1}$, Novriansyah ${ }^{2}$, Muhammad Imam Rahmatullah ${ }^{3}$, Candra Widiastuti ${ }^{4}$, Sigit Dwi Andrianto ${ }^{5}$

parctice with the internal imagery method with low self-efficacy, with a significant value of $0.000<0.05$.

Other pairs of groups that did not have significant differences were: (1). A1B1A2B1, (2). A1B1-A1B2, (3). A1B1-A2B2, (4). A2B1-A1B1, (5). A2B1-A2B2, (6). A1B2-A1B1, (7). A1B2-A2B2 (8). A2B2A1B1, (9). A2B2-A2B1, (10). A2B2-A1B2. It concluded:

a. A1B1-A2B1 : If a group of students in basketball extracurricular who are parctice with the internal imagery method with high self-efficacy is paired with a group of students in basketball extracurricular who are parctice with the external imagery method with high selfefficacy, then there are no significant differences, with a significance value of $0.300>0.05$.

b. A1B1-A1B2: If a group of students in basketball extracurricular who are parctice with the internal imagery method with high self-efficacy is paired with a group of students in basketball extracurricular who are parctice with the internal imagery method with low selfefficacy, then there are no significant differences, with a significance value of $0.053<0.05$.

c. A1B1-A2B2: If a group of students in basketball extracurricular who are parctice with the internal imagery method with high self-efficacy is paired with a group of students in basketball extracurricular who are parctice with the external imagery method with low self- efficacy, then there are no significant differences, with a significance value of $0.934<0.05$.

d. A2B1-A1B1: If a group of students in basketball extracurricular who are parctice with the external imagery method with high self-efficacy is paired with a group of students in basketball extracurricular who are parctice with the internal imagery method with high selfefficacy, then there are no significant differences, with a significance value of $0.300<0.05$.

e. A2B1-A2B2: If a group of students in basketball extracurricular who are parctice with the external imagery method with high self-efficacy is paired with a group of students in basketball extracurricular who are parctice with the external imagery method with low selfefficacy, then there are no significant differences, with a significance value of $0.101<0.05$.

f. A1B2-A1B1: If a group of students in basketball extracurricular who are parctice with the internal imagery method with low self-efficacy is paired with a group of students in basketball extracurricular who are parctice with the internal imagery method with high selfefficacy, then there are no significant differences, with a significance value of $0.053<0.05$.

g. A1B2-A2B2: If a group of students in basketball extracurricular who are parctice with the internal imagery method with low self-efficacy is paired 
Journal of Sport Education (JOPE), 3 (1) 2020 - 8

Fitri Agung Nanda ${ }^{1}$, Novriansyah ${ }^{2}$, Muhammad Imam Rahmatullah ${ }^{3}$, Candra Widiastuti ${ }^{4}$, Sigit Dwi Andrianto ${ }^{5}$

with a group of students in basketball extracurricular who are parctice with the external imagery method with low selfefficacy, then there are no significant differences, with a significance value of $0.181<0.05$.

h. A2B2-A1B1: If a group of students in basketball extracurricular who are parctice with the external imagery method with low self-efficacy is paired with a group of students in basketball extracurricular who are parctice with the internal imagery method with high selfefficacy, then there are no significant differences, with a significance value of $0.934<0.05$.

i. A2B2-A2B1: If a group of students in basketball extracurricular who are parctice with the external imagery method with low self-efficacy is paired with a group of students in basketball extracurricular who are parctice with the external imagery method with high selfefficacy, then there are no significant differences, with a significance value of $0.101<0.05$.

j. A2B2-A1B2: If a group of students in basketball extracurricular who are parctice with the external imagery method with low self-efficacy is paired with a group of students in basketball extracurricular who are parctice with the internal imagery method with low selfefficacy, then there are no significant differences, with a significance value of $0.181<0.05$.

The results of the variant analysis of advanced test using the post hoc test showed that there were two groups of significantly different pairs, namely: (1). A2B1-A1B2, (2). A1B2-A2B1. While 10 other pairs stated no differences, that is: (1). A1B1-A2B1, (2). A1B1-A1B2, (3). A1B1-A2B2, (4). A2B1A1B1, (5). A2B1-A2B2, (6). A1B2-A1B1, (7). A1B2-A2B2 (8). A2B2-A1B1, (9). A2B2-A2B1, (10). A2B2-A1B2. Based on the results of the data analysis, showed that there were no significant differences between the interactions of the imagery training and self-efficacy toward the ability of shooting free throw on participants of basketball extracurricular. The results of the research show that the external imagery training method gives a better effect compared to the internal imagery training in influencing the shooting free throw ability of basketball extracurricular. While the second hypothesis shows that participants with high selfefficacy categories are better than students with low categories toward the shooting free throw abilities of basketball extracurricular. The third hypothesis shows that there are no significant differences between the interaction of imagery training and selfefficacy toward the shooting free throw abilities of basketball extracurricular. This can be seen in the result sig $=.835>0.05$. In short, it stated that there is no interaction between imagery training and self-efficacy toward the shooting free throw abilities of basketball extracurricular.

\section{Discussion}

The results showed that there was no 
Journal of Sport Education (JOPE), 3 (1) 2020 - 9

Fitri Agung Nanda ${ }^{1}$, Novriansyah ${ }^{2}$, Muhammad Imam Rahmatullah ${ }^{3}$, Candra Widiastuti ${ }^{4}$, Sigit Dwi Andrianto ${ }^{5}$

influence of the psychological aspects, specially of toward the results of shooting free throws among the students of basketball extracurricular activity. The results contradicted with the previous studies or theories which suggested that psychological aspects had an impact on sports. In line with the previous opinion, Komarudin, (2010) states that training on psychology among athlete needs to perform during training. The psychological training is self-talk, imagery, concentration, and other intervention methods appropriate to the conditions experienced by athletes. The strategy or approach of the coach and psychologist in intervening must always show a good attitude, that is, being optimistic, and humoring because those can help improve team relationships, help athletes to stay focus on the task being studied, help prevent fatigue and stimulate a more pleasant atmosphere in the training experience of the team. The psychological training can improve performance in sports to achieve the desired goals. Hidayat, (2010) explains that psychological skills through a model of three exogenous latent constructs (self-talk, goal setting, and mental imagery), three endogenous latent constructs (self-efficacy and sports motivation as mediators), and sports performance in badminton. This shows that the construct of psychological aspects has a relationship between one another towards the athlete's achievement. Imagery training is a technique used by sports psychologists to help a person visualize or train his mind, that is relevant to the activities (Herfiantoro, Setyawati, \& Soekardi, 2019: 154).

Wulandari \& Janna, (2018) found out that the effect of the athlete's imagery and selfefficacy on the $100 \mathrm{~m}$ sprint athlete. Furthermore, these two aspects had a significant influence simultaneously for the success of $100 \mathrm{~m}$ sprint athletes. This study used an experimental method with one group pre-and post-test design with the results of the study showing there is an influence of PETTLEP Imagery on increasing the selfefficacy of $100 \mathrm{~m}$ sprint athletes individually. Mardhika \& Dimyati (2015) found out that have a significant between the imagery training and the concentration training method on the success of penalty kicks, seen by the $\mathrm{p}$-value $=0.002<0.05$; there is a significant difference affect between soccer players who had high self-efficacy and low self-efficacy towards the success of penalty kick, seen by the p-value $=0.012<0.05$; there is an interaction between mental training methods and self-efficacy in the success of the penalty kick, seen by the pvalue $=0.004<0.05$. Sukartidana, (2019) states that psychological skills in aspects of imagery training and self efficacy increase the athlete's concentration. Furthermore, he explains that this study is experimental, which means that there is a trial group and not tested. The results were significant increase in self-efficacy of sig $0,000<0.05$, and increase in concentration of sig 0,000 $<0.05$. The results of the t-test on the self-talk training method were significant towards an increase in confidence of $0.001<0.05$ and an 
Fitri Agung Nanda ${ }^{1}$, Novriansyah ${ }^{2}$, Muhammad Imam Rahmatullah ${ }^{3}$, Candra Widiastuti ${ }^{4}$, Sigit Dwi Andrianto ${ }^{5}$

increase in the concentration of $0.003<0.05$.

Effendi, (2016) explains that, in sports coaching, psychological aspects are one of the factors that influence the success of achievement. Psychological and behavioral factors are; achievement motives, intelligence, self-actualization, independence, aggressiveness, emotions, self-efficacy, motivation, enthusiasm, sense of responsibility, social sense, desire to win and so on. Sports psychology is very important in fostering the achievement of sports. Some of the benefits of sports psychology in improving athlete achievement are; it explain and understand the athlete's behavior and psychological symptoms that occur in sports in general, predict or make predictions accurately the possibilities that might occur in athletes, related to psychological problems, and can control behavioral symptoms in sports; with treatments to cope with unprofitable things, and also provide treatments to develop abilities and positive aspects possessed by athletes. Juriana, Tahki, \& Zulfitranto (2018) found out that knowledge about the psychology of sports for swimming coaches is very good both to support the success of swimming athletes in a match, learn aspects of good psychological skills such as mental skills and others that will affect the success of athletes in line with the goal of the match. The results showed that the lack of application and knowledge regarding an athlete's psychological skills which is known by the coach. Here, there is a need for an update of psychological skills and aspects with the aim to win the match.

Robina, Toussaint, Charles-Charlery, \& Coudevylle, (2019: 6) states that the group received imagery training have a higher increase, such in terms of accuracy in the shooting but did not have a big effect on physical improvement. The training methods in this study were internal and external imagery. Internal imagery is a technique used by students to imagine a situation as a firstperson perspective. Cox, (2011: 276), internal imagery is a natural thing for a person because a person through internal imagery can see himself in doing certain movements in his mind. In internal imagery, students are helped by using scripts. Yu et al., (2015: 6) states that people who do external imagery training will have a higher level of skill compared to people who do internal imagery whose skill scores are relatively lower. To get a shadow, it needs an external stimulus, such as a video or demonstration of a trainer about the technique. In the two training programs, the external imagery training method has a better impact than the internal imagery. Conducting psychological skills training on mental aspects and self-efficacy is a strategic technique in helping athletes to success in sport (Durand-Bush \& Salmela, 2002). Pulungan \& Dimyati, (2019) revealed that psychological skills which included imagery were important factors in supporting the success of volleyball playing.

Also, the increased competitive activity in a basketball athlete is influenced by good psychological quality and is very influential 
Journal of Sport Education (JOPE), 3 (1) 2020 - 11

Fitri Agung Nanda ${ }^{1}$, Novriansyah ${ }^{2}$, Muhammad Imam Rahmatullah ${ }^{3}$, Candra Widiastuti ${ }^{4}$, Sigit Dwi Andrianto 5

on athlete performance (Rovniy \& Pasko, 2017). Saleh \& Saleh, (2019) revealed that kinesthetic and motivation are important factors that must be considered in physical education learning activities. Further disclosed if these two factors greatly affect the success of student learning outcomes Nanda \& Dimyati, (2019) revealed that emotional intelligence is part of psychological skills which is an important factor in supporting the success of achievements achieved by individuals.

\section{CONCLUSION}

Based on the results of data analysis and discussions, the conclusion of the research was; there is no siginificat of imagery practice and self-efficacy toward in field of shooting free throw abilities of basketball extracurricular. This means that there is no influence of these two variables in the success of the shooting free throw.

\section{REFERENCES}

Castagna, C., Impellizzeri, F. M., Rampinini, E., D’Ottavio, S., \& Manzi, V. (2008). The Yo-Yo intermittent recovery test in basketball players. Journal of Science and Medicine in Sport, 11(2), 202-208. https://doi.org/10.1016/j.jsams.2007.02. 013

Cox, R. H. (2011). Sport Psychology Concepts and Applications. columbia: Mc Graw Hill. https://doi.org/10.4324/9781315885094
Durand-Bush, N., \& Salmela, J. H. (2002). The development and maintenance of expert athletic performance: Perceptions of world and olympic champions. Journal of Applied Sport Psychology, 14(3), 154-171. https://doi.org/10.1080/1041320029010 3473

Effendi, H. (2016). Peranan psikologi olahraga dalam meningkatkan prestasi atlet. Nusantara ( Jurnal Ilmu Pengetahuan Sosial ), 1.

FIBA. (2012). Peraturan Resmi Bola Basket. Indonesia: FIBA.

Herfiantoro, A., Setyawati, H., \& Soekardi. (2019). The Effect of Imagery Exercises and Emotional Quotient on the Athletes' Anxiety Level, 8(2), 153159.

Hidayat, Y. (2010). Model persamaan struktural teoretis sport performance: Analisis-Sintesis Perspektif Psikologis dalam Cabang Olahraga Bulutangkis. Jurnal Kepelatihan Olahraga, 2(1), 28 40.

Irianto, Djoko, P. (2018). Dasar - Dasar Latihan Olahraga Untuk Menjadi Atlet Juara. yogyakarta: Pohon Cahaya.

Juriana, Tahki, K., \& Zulfitranto, G. (2018). Pengetahuan Psikologi Olahraga Pada Pelatih Renang Indonesia. Jurnal Ilmiah Sport Coaching and Education, 2, 31-38. 


\section{Journal of Sport Education (JOPE), 3 (1) 2020 - 12}

Fitri Agung Nanda ${ }^{1}$, Novriansyah ${ }^{2}$, Muhammad Imam Rahmatullah ${ }^{3}$, Candra Widiastuti ${ }^{4}$, Sigit Dwi Andrianto ${ }^{5}$

Komarudin. (2010). Penerapan Psikologi Dalam Meningkatkan Penampilan Atlet. Jurnal Kepelatihan Olahraga, 2(2).

Mardhika, R., \& Dimyati. (2015). Pengaruh Latihan Mental Dan Keyakinan Diri Terhadap Keberhasilan Tendangan Penalti Pemain Sepak Bola. Jurnal Keolahragaan, 3(1), 106-116.

Nanda, F. A., \& Dimyati. (2019). Psychological Skills of Indonesian Basketball Athletes in Asian Games 18, $8(1), 37-43$.

Post, P. G., Wrisberg, C. A., \& Mullins, S. (2010). A field test of the influence of pre-game imagery on basketball free throw shooting. Journal of Imagery Research in Sport and Physical Activity, 5(1), 1-15. https://doi.org/10.2202/1932-0191.1042

Pulungan, K. A., \& Dimyati. (2019). The psychological skill characteristics of Indonesian volleyball players reviewed based on gender and position

Robina, N., Toussaint, L., Charles-Charlery, C., \& Coudevylle, G. R. (2019). Free throw performance in non-expert basketball players: The effect of dynamic motor imagery combined with action observation. Learning and Motivation, 68. https://doi.org/10.1016/j.lmot.2019.101 595
Rovniy, A., \& Pasko, V. (2017). The Role Of Psychological Qualities In The Process Of The Formation Of Sports Skill, 4(40), 118-121.

Saleh, M. S., \& Saleh, M. S. (2019). pendidikan jasmani The influence of kinesthetics, attitude and motivation on the learning results of sports education

Sudjana. (2002). Desain dan analisis eksperimen. Bandung: Tarsito.

Sugiyono. (2018). Metode Penelitian Kombinasi. Bandung: Alfabeta.

Sukartidana, I. N. (2019). Pengaruh Latihan Imagery dan Self Talk Terhadap Percaya Diri dan Konsentrasi Pada Siswa Ekstrakurikuler Bola Voli SMP N 51 Surabaya I. Jendela Olahraga, 4(1), 49-54. https://doi.org/10.26877/jo.v4i1.2991

Suryosubroto. (2007). Proses Belajar Mengajar Di Sekolah. jakarta: PT. Rineka Cipta.

Weinberg, R. ., \& Gould, D. (2011). Foundation Of Sport and Exercise Psychology. United States: Human Kinetics.

Wibowo, Y. ., \& Andriyani, F. (2015). Pengembangan Ekstrakurikuler Olahraga Sekolah. yogyakarta: UNYPRESS.

Wissel, H. (2012). Steps to success Basketball. United States: Human 


\section{Journal of Sport Education (JOPE), 3 (1) 2020 - 13}

Fitri Agung Nanda ${ }^{1}$, Novriansyah ${ }^{2}$, Muhammad Imam Rahmatullah ${ }^{3}$, Candra Widiastuti ${ }^{4}$, Sigit $^{-}$ Dwi Andrianto ${ }^{5}$

Kinetics.

Wulandari, Y. A., \& Janna, M. (2018).

Pengaruh PETTLEP Imagery Terhadap

Efikasi Diri Atlet Lari 100 Meter

Perorangan. Jurnal Psikologi Teori Dan

Terapan, 8(2), 154-164.

Yu, Q. H., Fu, A. S. N., Kho, A., Li, J., Sun,

X. H., \& Chan, C. C. H. (2015).

Imagery perspective among young

athletes: Differentiation between

external and internal visual imagery.

Journal of Sport and Health Science,

211-218.

https://doi.org/10.1016/j.jshs.2014.12.0

08

Ziv, G., \& Lidor, R. (2010). Vertical jump in female and male volleyball players: A review of observational and experimental studies. Scandinavian Journal of Medicine and Science in Sports, 20(4), 556-567. https://doi.org/10.1111/j.16000838.2009.01083.x 